\title{
SEDIMENT DYNAMICS AND STABILITY STATUS OF THE KARRA KHOLA, HETAUDA DUN VALLEY, CENTRAL NEPAL SUB-HIMALAYA
}

\author{
Naresh Kazi Tamrakar ${ }^{1}$, Suman Maharjan ${ }^{* 1}$ 四 \\ ${ }^{* 1}$ Central Department of Geology, Tribhuvan University, Kirtipur, Kathmandu, Nepal
}

DOI: https://doi.org/10.29121/ijetmr.v7.i11.2020.815

Article Citation: Naresh Kazi Tamrakar, and Suman Maharjan. (2020). SEDIMENT DYNAMICS AND STABILITY STATUS OF THE KARRA KHOLA, HETAUDA DUN VALLEY, CENTRAL NEPAL SUB-HIMALAYA. International Journal of Engineering Technologies and Management Research, 7(11), 50-68. https://doi.org/10.29121/ijetmr.v7 .i11.2020.815

Published Date: 30 November 2020

Keywords:

Fluvial Sediment

Sediment Transport

Specific Stream Power

Flow Competency

Stability

\section{ABSTRACT}

The Karra Khola in Hetauda, Siwalik region, originates within the Dun Valley, and contributes the Rapati Nadi in Hetauda Metropolitan city. The stability status of the river is of main concern because of rapid growing of the river corridor and peripheral land areas into suburban city. The river was surveyed for hydraulic parameters, sediment characteristics, and sediment loads. Rate of sediment transport and sediment yields were computed, and competency of the river was evaluated using Shield's parameters and Reynolds numbers. The results show that the river sediments are sandy gravel to gravelly sands, and are moderately to very poorly sorted. The total sediment yield of the whole basin near the outlet is around $2 \%$ of the maximum total sediment yield. The specific stream power (SSP) ranges from 20.98 to $2866.34 \mathrm{Wm}^{-2}$. The dimensionless boundary shear stress to dimensionless critical shear stress ratio exceeds unity, revealing that the river is competent enough to transport its bed material loads, except in downstream stretch before the river confluences with the Rapati Nadi. The Karra Khola clearly exhibits status of degradation in the upstream stretch, high rates of transportation due to lateral erosion in the midstream stretch, and aggradation in the downstream stretch.

\section{INTRODUCTION}

The Siwalik Group is comprised of Late Miocene to Early Pleistocene sedimentary sequence deposited in the foreland basin of the uplifting Himalaya (Tokuoka et al. 1986, Kizaki 1994, Critelli and Ingersoll 1994, DeCelles et al. 1998, Gautam and Rosler 1999). Galay (1987) explained that the steep slopes of the Siwalik Hills and weakly consolidated rocks with thin soil cover generally tends to promote severe surface erosion in spite of the thick vegetation. Likewise, Shrestha et al. (2005) also suggested that the apparent reason for the huge sedimentation within the Siwalik basins could be because of fluvial characteristics. Tamrakar and Karki (2019) concluded that there were variation in specific sediment yields and sediment delivery ratio among the sub-basins of the Karra Khola, and reported that specific sediment yields were lower in most of the southern sub-basins compared to the northern subbasins of the Karra Khola, due to topography and streambed characteristics.

Erosion, transportation and deposition of sediments depend upon hydraulic action, which is again governed by topography and climate (Grantham and Velbel 1988), tectonics and weathering (Johnson 1990), composition of source area (Dickinson et al. 1983, Dickinson et al. 1986) and riverbed materials (Cavazza et al. 1993, Cox and Lowe 1995). Deposition occurs when the critical shear stress required to entrain particles of a specific size exceeds

(C) 2020 The Author(s). This is an open access article distributed under the terms of the Creative Commons Attribution License, which permits unrestricted use, distribution, and reproduction in any medium, provided the original author and source are credited. 
boundary shear stress, if the case is opposite, then the sediment gets entrained and transported. Several researchers have formulated the sediment transport using the concept of bed shear stress or unit flow discharge based on field and laboratory experiments (Du boys 1879, Schoklitsch 1934, Shields 1936, Meyer-Peter and Muller 1948, Einstein 1950, Bagnold 1966, Yang 1972, Van Rijn 1984). Hassanzadeh (2007) presented a dimensionless semi-empirical formula on the bed load, and showed that the values obtained from the formula were closer to the measured data than the common ones on sediment hydraulics.

The behavior of river can be understood by its sediment transport capacity and flow competence. The sediment transport capacity is the river's capacity to transport the total amount of its load across the specific site of the river bed (Bagnold 1960,1966). It can be expressed in terms of sediment total load carried or in terms of river's energy required to transport sediment per unit bed surface area, which is expressed as the unit stream power or specific stream power (Bagnold 1966). Several researchers expressed usefulness of unit stream power in interpreting risk of erosion of the stream, and channel sensitivity to erosion and deposition (Gilbert 1914, Rubey 1933, Velikanov 1955, Brookes 1987, Miller 1990, Magilligan 1992, Rathburn 1993, Ferguson 2005, Petit et al. 2005, Mao et al. 2008, Thompson and Croke 2013, Bizzi and Lerner 2015, Soar et al. 2017, Yochum et al. 2017).

Stream flow competence is stream's ability to entrain and move the available bed materials of desired size grades that are often median grain size (Wilcock 1971). Generally, incipience happens when the boundary shear stress of the stream overcomes the critical shear stress of the bed material (Shields 1936, Knighton 1998). Several researches of flow competence progressed for various rivers (Lorang and Hauer 2003, Whitaker and Potts 2007, Lama and Tamrakar 2016, Mua and Shende 2019). Commonly, rivers with high capacity but low competence tend to deposit sediments, those with high capacity, high competence tend to transport enormous amount of sediment, and those with low capacity but with high competence tend to degrade river to achieve a dynamic equilibrium. The present study aims to establish sediment flow dynamics, dealing first with the sediment transport capacity and its bearing on potential risk of erosion, and secondly with the competency of the Karra Khola that is an axial river originated and flowing in the Dun Valley of the Siwaliks, central Nepal (Fig. 1). The status of capacity and competency of the Karra Khola leads to evaluation of stability of the river.

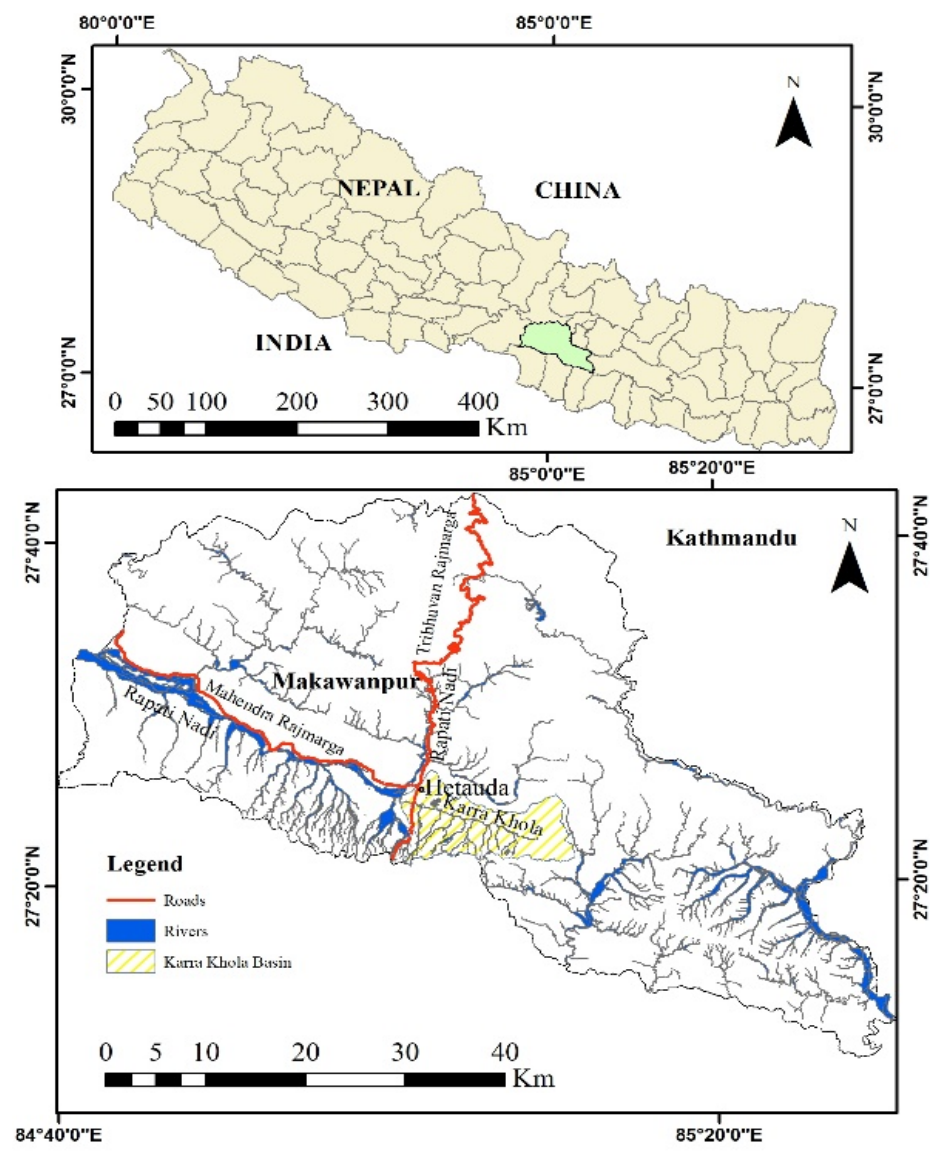

Figure 1: Map showing location of the study area 


\section{GEOLOGICAL SETTING OF THE STUDY AREA}

The Karra Khola Basin (KKB) spans for 6-9 km in width and 17-18 km in length, and comprises of the Siwalik Hills, which are composed of middle Miocene to early Pleistocene molasse sediments of the Siwalik Group (West and Munthe 1981, Tokuoka et al. 1986). The two belts of the Siwalik Group are separated by the Main Dun Thrust (MDT) along which the Lower Siwalik Subgroup of the northern belt overthrusts the Upper Siwalik Subgroup of the southern belt (Fig. 2). The northern belt Siwaliks are folded as the Ratomate Syncline and the Karra Khola Anticline (Schelling et al. 1991, Kimura 1994, Kimura 1995, Tamrakar and Karki 2019), whereas the southern belt Siwaliks are gently north dipping homocline. The KKB covers portions of both the northern and the southern belts of the Siwalik Group. It was created due to the thrusting along the MDT, and then progressive upliftment of the Chure Range as a consequence of the thrusting along the Main Frontal Thrust, located further south of the basin.

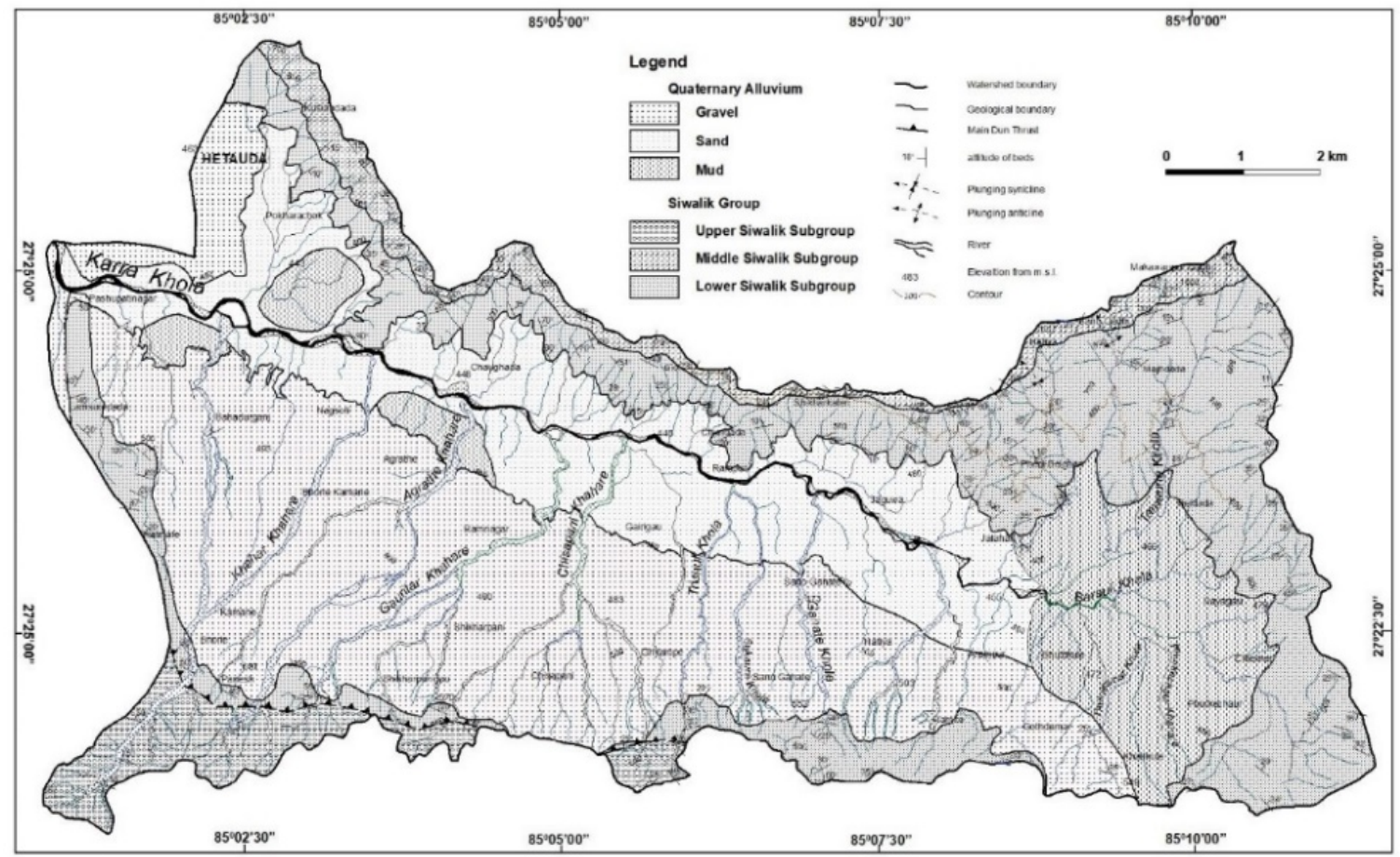

Figure 2: Geological map of the study area. (After Tamrakar and Karki 2019)

The southern part of the KKB consists of thick conglomerates with few intercalations of mudrock and sandstone of the Upper Siwalik Subgroup that forms the major part of the Churiya Hills and divides the southern boundary of the KKB. The northern portion of the KKB consists of intercalation of mudrock and sandstone of the Lower Siwalik Subgroup followed by thick salt and pepper sandstones with alternation of silt-shale, mudstone, and clay-shale of the Middle Siwalik Subgroup. Both the Lower and the Middle Siwalik Subgroups cropping out in the northern portion of the KKB show NW-SE strike and steep NE dipping (Fig. 2).

The unconsolidated Quaternary Alluvial sediments, which are the basin-fill sediments, have been deposited since the Mid-Pleistocene to Recent (Kimura 1994), and unconformably overlie the Siwalik rocks of both belts, mostly covering the wide extension of the central portion of the KKB. These Quaternary Alluvial sediments consist of coarse to fine grained sediments originated within the $\mathrm{KKB}$, and can be distinguished into three morpholithological zones; Upper, Middle and Lower (Tamrakar and Karki 2019). The Upper zone comprises of bouldercobble to pebble-cobble gravel, the Middle zone of cobble-pebble gravel and sand, and the Lower zone of pebbly sand, sand and mud.

The emerging point of the main stem Karra Khola is located in the Siwalik Hills, at the upstream head of the Tamaune Khola, somewhere at Makawanpur Gadhi (Fig. 2). Upto the confluence of the Tamaune Khola and the Barauli Khola, the gradient of the main stem Karra Khola is quite steep, and further downstream the gradient lowers abruptly, and then diminishes gradually (Fig. 3). 


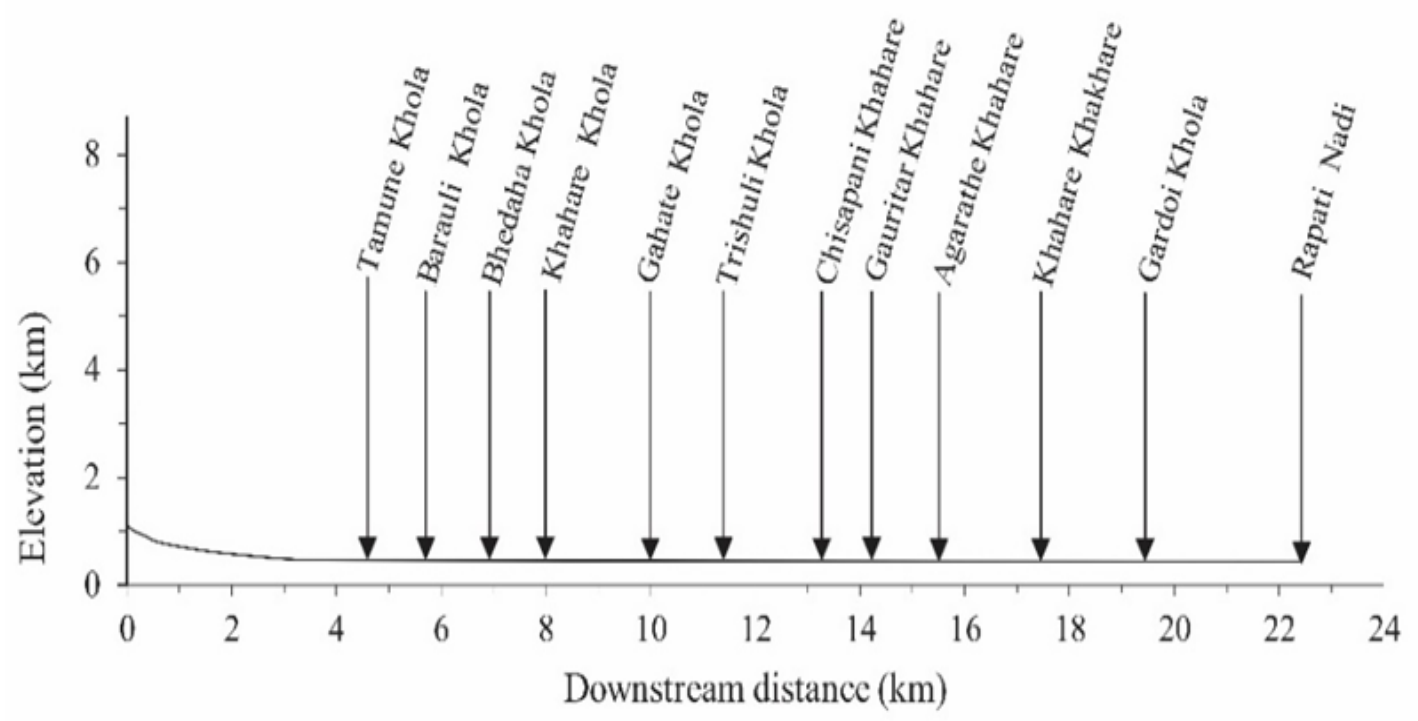

Figure 3: Longitudinal profile of the Karra Khola

The main stem Karra Khola is the 5th order river and its major tributaries are the Gahate Khola, Trishuli Khola, Chisapani Khahare, Gauritar Khahare, Agarathe Khahare, and Khahar Khahare, which originate from the southern part of the basin (Fig. 4), and all are intermittent streams that contribute towards the left banks of the Karra Khola. The Bhedaha and Gardoi Kholas are remarkable tributaries from the northern portion and contribute to the right banks of the Karra Khola. Therefore, the main stem Karra Khola appears as an axial drainage in the basin.

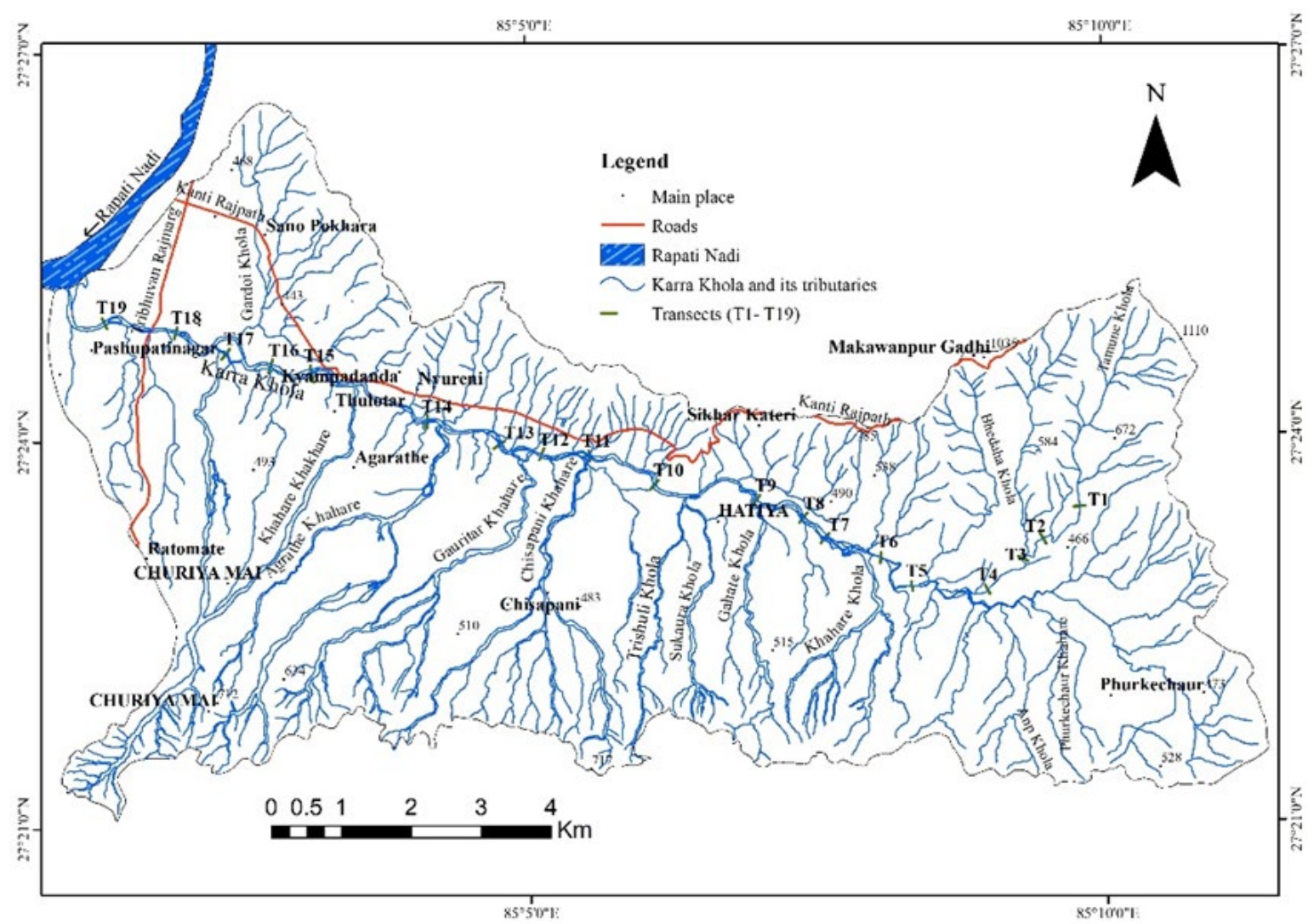

Figure 4: A map showing sampling sites 


\section{METHODOLOGY}

The main stem Karra Khola was surveyed for recording the nature of sediment distribution along the river channel and banks. A sediment distribution map was prepared in 1:10,000 scale. Altogether 19 main stem transects, which were continuously from the transect number T1 to T19, were selected for the cross sectional and longitudinal surveys. Cross-sections of all transects were prepared to obtain hydraulic parameters of the river. Along each transects, channel sediments were assessed applying the Wolman pebble counting method (Wolman 1954, Rosgen 1996). The grain size distribution of the channel sediments were processed through graphic statistical measures after Folk and Ward (1957).

The Karra Khola Basin lacks gauging station, therefore, velocity (V) and discharge (Q) of the Karra Khola were estimated using the Manning's Formula and the continuity equation (Chow 1959):

$$
\begin{gathered}
\mathrm{V}=\left(\mathrm{R}^{2 / 3} \cdot \mathrm{S}^{1 / 2}\right) / \mathrm{n} \\
\mathrm{Q}=\mathrm{V} \cdot \mathrm{A}
\end{gathered}
$$

Where, $\mathrm{V}=$ velocity $\left(\mathrm{ms}^{-1}\right), \mathrm{R}=$ hydraulic radius $(\mathrm{m})$, a ratio of cross-sectional area $(\mathrm{A})$ to wetted perimeter $(\mathrm{P})$, $S=$ average channel slope $\left(\mathrm{mm}^{-1}\right)$, and $\mathrm{n}=$ Manning's roughness coefficient.

The Manning's roughness coefficient, $n$ at each transect was estimated by firstly calculating the basin roughness value using the equation of Limerinos (1970) and then inserting this value along with estimated adjustment values in the equation of Cowan (1956) as below:

$$
\begin{aligned}
& n_{0}=\frac{(0.11288) R^{1 / 6}}{1.16+2.0 \log \left(R / d_{84}\right)} \ldots \ldots \ldots \ldots \ldots \ldots \\
& n=\left(n_{0}+n_{1}+n_{2}+n_{3}+n_{4}\right) m \ldots \ldots \ldots \ldots
\end{aligned}
$$

Where, $\mathrm{R}=$ hydraulic radius $(\mathrm{m}), \mathrm{d}_{84}=$ intermediate particle diameter (in meter), that equals or exceeds that of 84 percent of the particles, $\mathrm{n}_{0}=$ base value, $\mathrm{n}_{1}=$ additive value to account for the effect of cross-section irregularity, $\mathrm{n}_{2}=$ additive value to account for the variations in size and shape of the channel, $\mathrm{n}_{3}=$ additive value to account for the effect of obstructions, $\mathrm{n}_{4}=$ additive value to account for the type and density of vegetation, and $\mathrm{m}=$ adjustment factor for the degree of channel meandering that is the ratio of channel meander length to the straight channel length.

The water samples collected from each of the transects more or less at the bankfull stage were filtered in the laboratory using filter of uniform pores $(0.45 \mu \mathrm{m})$ to calculate the suspended sediment load carried by the stream. The suspended sediment concentration (SSC) was calculated as the ratio of the dry mass of suspended sediment retained to the volume of water sample taken to filtration.

The total bed-material was computed by analysing the frequency distribution of particle sizes within a bedmaterial sample, and then incorporating hydraulic parameters in the expression of Hassanzadeh (2007) bedload equation, which is expressed as:

$$
\begin{aligned}
& q_{b}=24 f^{2.5}\left(\operatorname{agd}^{3}\right)^{1 / 2} \\
& f=\tau_{b} /\left(\gamma_{s}-\gamma\right) d \\
& \mathrm{a}=\left(\gamma_{\mathrm{s}}-\gamma\right) / \gamma \\
& \tau_{b}=\gamma R_{h} S
\end{aligned}
$$


Where, $\mathrm{q}_{\mathrm{b}}=$ bedload in $\mathrm{m}^{2} \mathrm{~s}^{-1}, \mathrm{f}=$ hydrodynamic immersed gravity force ratio, $\mathrm{g}=$ acceleration due to gravity = $9.80 \mathrm{~ms}^{-2}, \mathrm{~d}=$ median grain diameter $\left(\mathrm{d}_{50}\right)$, a = immersed sediment specific gravity, $\gamma_{\mathrm{s}}-\gamma=$ submerged specific weight of sediment, $\mathrm{KNm}^{-3}, \gamma_{\mathrm{s}}=$ specific weight of sediment $=26.5 \mathrm{KNm}^{-3}, \gamma=$ specific weight of water $=9.807 \mathrm{KNm}^{-3}, \tau_{\mathrm{b}}=$ boundary shear stress. $R_{h}=$ hydraulic radius, and $S=$ slope, $\mathrm{mm}^{-1}$.

Now, the bedload transport capacity $\left(Q_{b}\right)$ was calculated using the relation:

$$
\mathrm{Q}_{\mathrm{b}}=\gamma_{\mathrm{s}} \mathrm{Wq}
$$

Where, $\mathrm{Q}_{\mathrm{b}}=$ bedload in KNs, $\mathrm{W}=$ width in meter, $\gamma=$ specific weight of sediment, $\mathrm{KNm}^{-3}$, and $\mathrm{q}_{\mathrm{b}}=$ bedload in $\mathrm{m}^{2} \mathrm{~s}^{-1}$.

The stream power $(\Omega)$ is the rate of potential energy expenditure against beds and banks of channel per unit length, and can be expressed using the following expression (Bagnold 1960, 1966):

$$
\Omega=\rho g Q S
$$

Where, $\Omega=$ stream power $\left(\mathrm{Ns}^{-1}\right), \rho=$ density of water $\left(\mathrm{kgm}^{-3}\right), \mathrm{g}=$ acceleration due to gravity, $\left(\mathrm{ms}^{-2}\right), \mathrm{Q}=$ hydraulic discharge of the stream $\left(\mathrm{m}^{3} \mathrm{~s}^{-1}\right)$ and $\mathrm{S}=$ stream slope $\left(\mathrm{mm}^{-1}\right)$.

The unit or specific stream power $(\omega)$ is defined as the total stream power $(\Omega)$ per unit width of the channel (W) (Bagnold 1966), and is expressed in $\mathrm{Wm}^{-2}$, where W stands for Watt.

$$
\omega=\Omega / \mathrm{W}
$$

The competence of the Karra Khola was evaluated by using shear stress criterion of Shields, and in this the dimensionless boundary shear stress $\left({ }^{*} \tau_{\mathrm{b}}\right)$ was calculated applying Shields criterion as below:

$$
\begin{aligned}
*_{\tau_{b}} & =\tau_{\mathrm{b}} /\left(\gamma_{\mathrm{s}}-\gamma\right) \mathrm{d}_{50} \\
\tau_{\mathrm{b}} & =\gamma \mathrm{R}_{\mathrm{h}} \mathrm{S} \ldots \ldots \ldots \ldots
\end{aligned}
$$

Where, $\tau_{b}=$ boundary shear stress $\left(\mathrm{Nm}^{-2}\right), \gamma=$ specific weight of water $\left(\mathrm{Nm}^{-2}\right), \mathrm{R}_{\mathrm{h}}=$ Hydraulic radius $(\mathrm{m}), \mathrm{S}=$ Average stream slope $\left(\mathrm{m} \mathrm{m}^{-1}\right), \gamma_{\mathrm{s}}=$ specific weight of sediment $=26500 \mathrm{Nm}^{-3}$, and $\mathrm{d}_{50}=$ median grain size. Then the dimensionless critical shear stress $\left(\tau_{\mathrm{c}}{ }^{*}\right)$ was obtained after computation of Reynolds number and extrapolating it using the Shields curve. The boundary Reynolds number was obtained using the following expression:

$$
\mathrm{R}_{\mathrm{e}^{*}}=\left(\mathrm{u}^{*} \mathrm{~d}_{50}\right) / v
$$

Where, $\mathrm{u}^{*}=$ shear velocity $\left(\mathrm{ms}^{-1}\right)=\left(\sqrt{ }\left(\tau_{\mathrm{b}} / \rho\right)\right), \tau_{\mathrm{b}}=$ boundary shear stress $\left(\mathrm{Nm}^{-2}\right), \rho=$ density of water $(1000 \mathrm{~kg}$ $\left.\mathrm{m}^{-3}\right), \mathrm{d}_{50}=$ median grain size $(\mathrm{m})$, and $v=$ hydraulic viscosity $\left(1.004 * 10^{-6} \mathrm{~m}^{2} \mathrm{~s}^{-1}\right)$. The stream transect site was taken as competent when the dimensionless boundary shear stress exceeded the dimensionless critical shear stress, otherwise it was regarded as incompetent. Then, both transport capacity and flow competence were considered with their thresholds to evaluate stability status of the river along its course.

\section{RESULTS}

\subsection{SEDIMENT DISTRIBITION AND CHARACTERISTICS IN THE KARRA KHOLA}

\subsubsection{CHANNEL BANK DEPOSIT}

As the stream descends from the higher relief areas to the flat plain downstream, the channel bank deposits are extensively developed (Fig. 5). The sediments in such depositional elements are laminated fine sand, sandy mud, 
muddy sand and gravelly mud. The sediments are relatively coarser in the banks near to the source regions compared to the banks of the downstream regions.

\subsubsection{CHANNEL SEDIMENTS}

There are many convex bends in the Karra Khola corridor where the point bar depositional features are frequently developed along the Karra Khola. The point bars of both sandy gravel and gravelly sands are observed (Fig. 5). The point bar deposits show thick layers of fine to medium grained pebbly sand fining up section into finegrained sand.

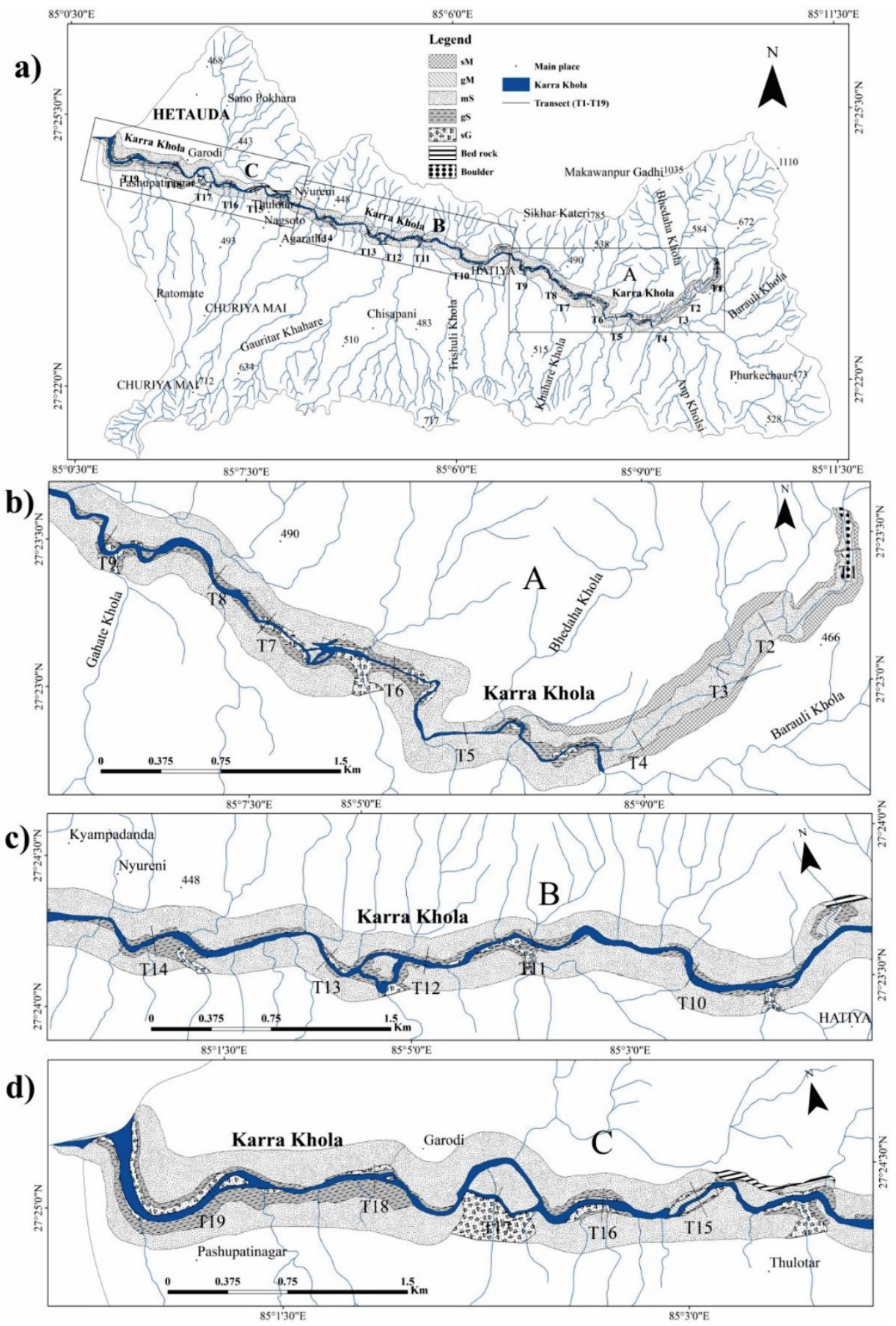

Figure 5: Sediment distribution map of the Karra Khola corridor 
The recent sediments along the Karra Khola is composed mainly of gravelly sand (gS), gravelly mud (gM), muddy sand ( $\mathrm{mS}$ ), sandy gravel (sG), and sandy mud (sM). The boulder sized sediments are present at the upstream channel, where coarse sediments are shed from mass wasting from the valley slopes. The sediment size decreases moving downstream and becomes sandy gravel to gravelly sand on both banks of the stream channel, but clast size fluctuates due to mixing of gravels from the intermitted contributing streams from lateral direction towards the confluence with the Karra Khola.

Grain size characteristics of the channel sediments of the Karra Khola were assessed (Table 1). The particles range from clay to boulder in most of transects of the Karra Khola. The mean size (Mz) varies between 57.947 and $0.293 \mathrm{~mm}$. The median size ranges from 2 to $73 \mathrm{~mm}$. Sorting $\left(\sigma_{\mathrm{I}}\right)$ of the Karra Khola sediments ranges from moderately well sorted to very poorly sorted. Sediments of the upstream stretch are more or less coarsely skewed, whereas those of mid to downstream stretches show nearly symmetrical to finely skewed, however, majority of transects (T3, T4, T9, T10, T11, T12, and T18) indicate finely skewed sediments. The peakedness or graphic kurtosis $\left(\mathrm{K}_{\mathrm{G}}\right.$ ) varies from very platykurtic (at T12 and T13) to leptokurtic (at T2 and T6), and the majority of transects are being characterized by the mesokurtic grain size distribution showing that the contrast to the median size with the background size remains moderate. Along the river course, the median size tends to increase except for some sites T3, T4 and T12 where the size diminishes or the size gets diluted (Table 1).

Table 1: Calculation of different statistical parameters of the Karra Khola

\begin{tabular}{|c|c|c|c|c|c|c|}
\hline $\begin{array}{c}\text { Transect } \\
\text { no. }\end{array}$ & $\begin{array}{c}\text { Downstream } \\
\text { Distance }(\mathrm{km})\end{array}$ & $\begin{array}{l}\text { Graphic } \\
\text { Mean } \\
(\mathrm{Mz})(\phi)\end{array}$ & $\begin{array}{c}\text { Median } \\
\mathrm{d}_{50}(\mathrm{~m})\end{array}$ & $\begin{array}{c}\text { *Inclusive Graphic } \\
\text { Standard Deviation, } \\
\sigma_{\mathrm{I}}(\phi)\end{array}$ & $\begin{array}{c}{ }^{* *} \text { Inclusive } \\
\text { Graphic } \\
\text { Skewness, } \mathrm{SK}_{\mathrm{I}} \\
\end{array}$ & $\begin{array}{l}{ }^{* * *} \text { Graphic } \\
\text { Kurtosis, } \mathrm{K}_{\mathrm{G}}\end{array}$ \\
\hline 1 & 3.4 & -4.23 & 0.018 & 2.52 (vps) & 0.17 (fs) & 1.61 (vlk) \\
\hline 2 & 4.09 & -2.88 & 0.011 & 2.30 (vps) & 0.4 (sfs) & $1.37(\mathrm{lk})$ \\
\hline 3 & 4.83 & 1.8 & 0.0002 & 0.63 (mws) & $-0.52(\mathrm{scs})$ & $1.001(\mathrm{mk})$ \\
\hline 4 & 5.34 & -0.43 & 0.001 & 1.05 (ps) & $-0.16(\mathrm{cs})$ & $0.75(\mathrm{pk})$ \\
\hline 5 & 6.54 & -4.68 & 0.025 & $0.76(\mathrm{~ms})$ & 0.17 (fs) & 1.54 (vlk) \\
\hline 6 & 7.94 & -4.3 & 0.021 & $1.04(\mathrm{ps})$ & 0.27 (fs) & $1.4(\mathrm{lk})$ \\
\hline 7 & 8.49 & -5.43 & 0.042 & $1.25(\mathrm{ps})$ & 0.12 (fs) & 1.51 (vlk) \\
\hline 8 & 9.27 & -4.56 & 0.027 & $1.34(\mathrm{ps})$ & 0.26 (fs) & $0.90(\mathrm{mk})$ \\
\hline 9 & 9.78 & -4.41 & 0.021 & $0.97(\mathrm{~ms})$ & $-0.01(\mathrm{~ns})$ & $0.97(\mathrm{mk})$ \\
\hline 10 & 11.88 & -4.8 & 0.027 & $1.18(\mathrm{ps})$ & $-0.006(\mathrm{~ns})$ & $0.98(\mathrm{mk})$ \\
\hline 11 & 13.24 & -5.06 & 0.033 & 0.67 (mws) & -0.007 (ns) & $1.02(\mathrm{mk})$ \\
\hline 12 & 13.85 & -1.08 & 0.002 & 3.30 (vps) & -0.002 (ns) & 0.59 (vpk) \\
\hline 13 & 14.45 & -2.25 & 0.012 & 2.82 (vps) & 0.64 (sfs) & 0.66 (vpk) \\
\hline 14 & 15.11 & -2.9 & 0.017 & 2.60 (vps) & 0.67 (sfs) & $0.98(\mathrm{mk})$ \\
\hline 15 & 17.41 & -4.98 & 0.039 & 2.63 (vps) & 0.36 (sfs) & 1.95 (vlk) \\
\hline 16 & 17.93 & -5.46 & 0.073 & 2.30 (vps) & 0.71 (sfs) & 1.64 (vlk) \\
\hline 17 & 18.52 & -5.55 & 0.048 & 2.44 (vps) & 0.25 (fs) & 1.81 (vlk) \\
\hline 18 & 19.53 & -5.78 & 0.053 & 0.61 (mws) & $-0.05(\mathrm{~ns})$ & $1.05(\mathrm{mk})$ \\
\hline 19 & 20.99 & -5.53 & 0.055 & 1.43 (ps) & 0.25 (fs) & $(\mathrm{mk})$ \\
\hline
\end{tabular}

*Inclusive Graphic Standard Deviation: vps- very poorly sorted, ps- poorly sorted, ms- moderately sorted, mwsmoderately well sorted

**Inclusive Graphic Skewness: ns- near symmetrical, cs- coarse skewed, fs- fine skewed, sfs- strongly fine skewed, scs- strongly coarse skewed

***Graphic Kurtosis: lk- leptokurtic, pk- platykurtic, mk- mesokurtic, vlk- very leptokurtic, vpk- very platykurtic

The channel sediments possess moderate to poor sorting in the upstream stretch, whereas from the midstream towards the downstream stretch, the sorting becomes notably poor to very poor (Table 1). Both skewness and 
Sediment Dynamics and Stability Status of The Karra Khola, Hetauda Dun Valley, Central Nepal Sub-Himalaya

peakedness fluctuate along the downstream course of the Karra Khola suggesting that the sediments vary within ranges of fine to coarse skewness, and moderately poorly to well sorting.

\subsection{HYDRAULIC PARAMETERS}

The morpho-hydraulic parameters (Table 2) were calculated during field survey. The channel cross-sectional area (A) at bankfull ranges from $1.12 \mathrm{~m}^{2}$ (T1) to $18.02 \mathrm{~m}^{2}$ (T19). The hydraulic radius (Rh) varies between between $0.27 \mathrm{~m}$ and $0.85 \mathrm{~m}$. The bankfull cross-sectional area in the midstream stretch grows roughly by ten times and that in the downstream stretch by 20 times compared to the bankfull cross-sectional area at the upstream stretch.

Table 2: Hydraulic parameters of Karra Khola from T1 to T19 and its tributaries

\begin{tabular}{|c|c|c|c|c|c|c|c|}
\hline $\begin{array}{c}\text { Transect } \\
\text { no. }\end{array}$ & $\begin{array}{c}\text { Cross- } \\
\text { section } \\
\text { Area }\left(\mathrm{m}^{2}\right)\end{array}$ & $\begin{array}{c}\text { Slope } \\
\left(\mathrm{mm}^{-1}\right)\end{array}$ & $\begin{array}{c}\text { Hydraulic } \\
\text { Radius }(\mathrm{m})\end{array}$ & $\begin{array}{c}\text { Velocity } \\
(\mathrm{V}),\left(\mathrm{ms}^{-1}\right)\end{array}$ & $\begin{array}{c}\text { Discharge } \\
(\mathrm{Q}),\left(\mathrm{m}^{3} \mathrm{~s}^{-1}\right)\end{array}$ & $\begin{array}{c}\text { Watershed } \\
\text { Area, }\left(\mathrm{km}^{2}\right)\end{array}$ & $\begin{array}{c}\text { Manning's n } \\
\text { value }\end{array}$ \\
\hline T1 & 1.12 & 0.066 & 0.27 & 1.39 & 1.55 & 4.23 & 0.075 \\
\hline T2 & 3.93 & 0.008 & 0.39 & 0.73 & 2.88 & 4.58 & 0.072 \\
\hline T3 & 1.60 & 0.0014 & 0.27 & 0.5 & 0.81 & 7.36 & 0.030 \\
\hline T4 & 2.50 & 0.0013 & 0.33 & 0.58 & 1.46 & 7.95 & 0.031 \\
\hline T5 & 5.00 & 0.0052 & 0.42 & 0.58 & 2.91 & 26.62 & 0.078 \\
\hline T6 & 10.60 & 0.0076 & 0.55 & 0.85 & 9.01 & 32.14 & 0.085 \\
\hline T7 & 12.29 & 0.0084 & 0.68 & 1.3 & 16.81 & 32.59 & 0.069 \\
\hline T8 & 7.10 & 0.0071 & 0.47 & 0.84 & 5.96 & 33.83 & 0.072 \\
\hline T9 & 8.42 & 0.0123 & 0.77 & 2.18 & 18.38 & 33.86 & 0.059 \\
\hline T10 & 11.70 & 0.007 & 0.67 & 0.85 & 10.04 & 44.41 & 0.099 \\
\hline T11 & 14.22 & 0.007 & 0.79 & 1.59 & 22.65 & 54.66 & 0.063 \\
\hline T12 & 12.48 & 0.0035 & 0.85 & 1.39 & 17.45 & 55.66 & 0.054 \\
\hline T13 & 11.10 & 0.0095 & 0.54 & 1.08 & 12.01 & 64.77 & 0.073 \\
\hline T14 & 9.25 & 0.0105 & 0.61 & 2.02 & 18.7 & 72.67 & 0.047 \\
\hline T15 & 12.96 & 0.009 & 0.44 & 1.01 & 13.11 & 80.34 & 0.063 \\
\hline T16 & 17.29 & 0.007 & 0.64 & 0.86 & 14.96 & 82.44 & 0.094 \\
\hline T17 & 10.60 & 0.006 & 0.56 & 0.85 & 9.06 & 84.73 & 0.077 \\
\hline T18 & 16.10 & 0.0052 & 0.65 & 0.99 & 15.95 & 92.58 & 0.072 \\
\hline T19 & 18.02 & 0.0062 & 0.62 & 0.89 & 16.18 & 97.8 & 0.082 \\
\hline
\end{tabular}

Manning's roughness coefficients vary from .03 (T3) to .099 (T10) for different transects. The upstream stretch (between T1 and T5) possess slightly entrenched channels with good riparian vegetation, and heterogeneous, coarse skewed sediments (e.g., Figs. 6a and b). The midstream stretch between T5 and T16 remains slightly entrentched to non-entrenched with wide channel and sparse riparian vegetation (e.g., Figs. 6c and d). The downstream stretch (downstream from T5) lacks good riparian vegetation, and channels are wide non-entrentched with abundant sediments deposited in the channel (e.g., Figs. 6e and f).

The velocity at bankfull ranges from $0.50 \mathrm{~ms}^{-1}$ (at T3) to $2.18 \mathrm{~ms}^{-1}$ (at T9), and exhibits fluctuating trend along downstream course. Discharge at bankfull varies between $0.81 \mathrm{~m}^{3} \mathrm{~s}^{-1}$ (at T3) and $22.65 \mathrm{~m}^{3} \mathrm{~s}^{-1}$ (at T11) (Table 2), and tends to increase downstream (Fig. 7a), with notable higher discharge in the midstream course of the Karra Khola. Discharge of the Karra Khola tend to increase, as the basin area increases (Fig. 7b). 

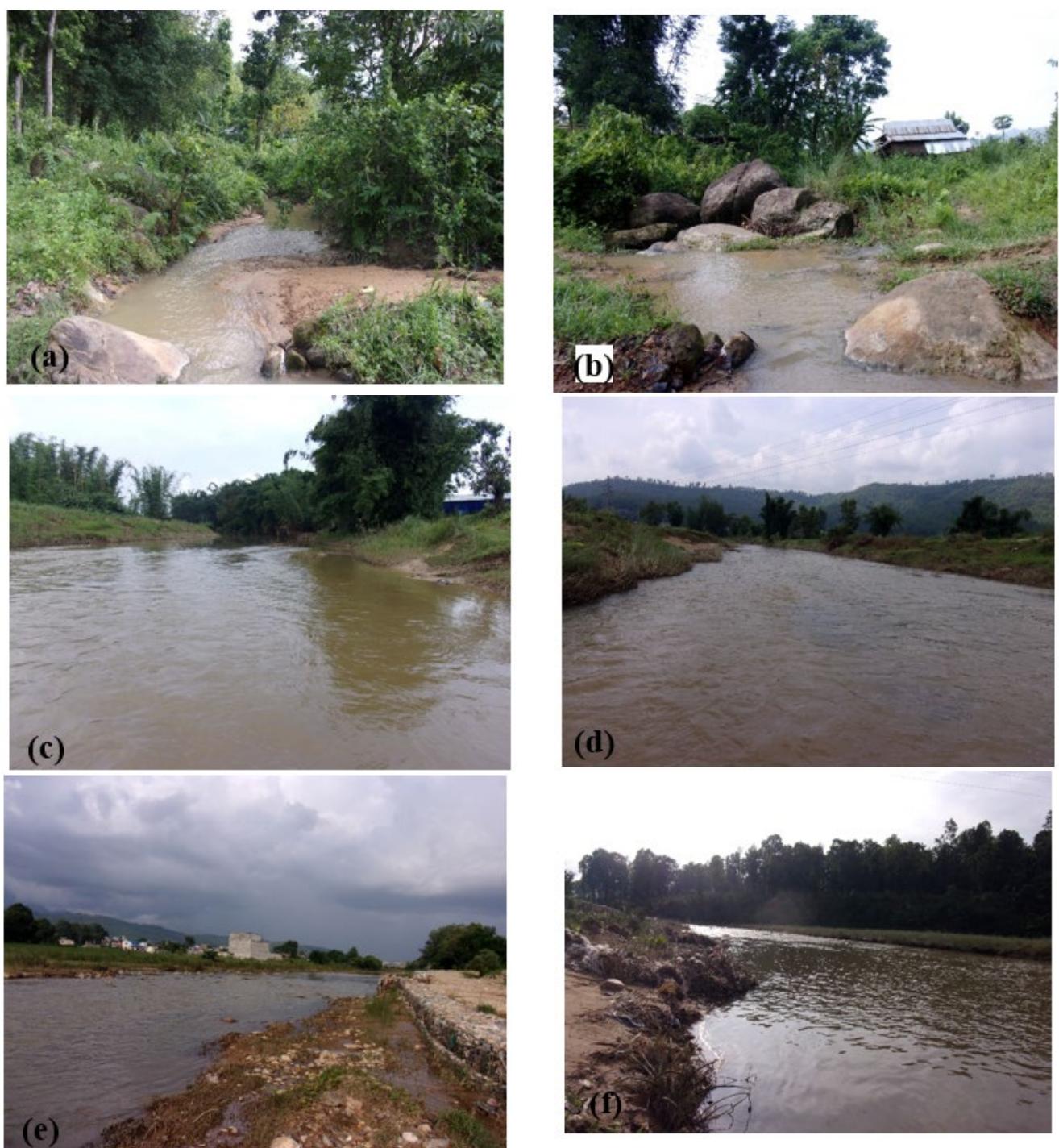

Figure 6: Upstream and downstream views of the Karra Khola: (a) upstream view from T1, (b) downstream view from T1, (c) upsream view from T13, (d) downstream view from T13, (e) upstream view from T19, and (f) downsteram view from T19
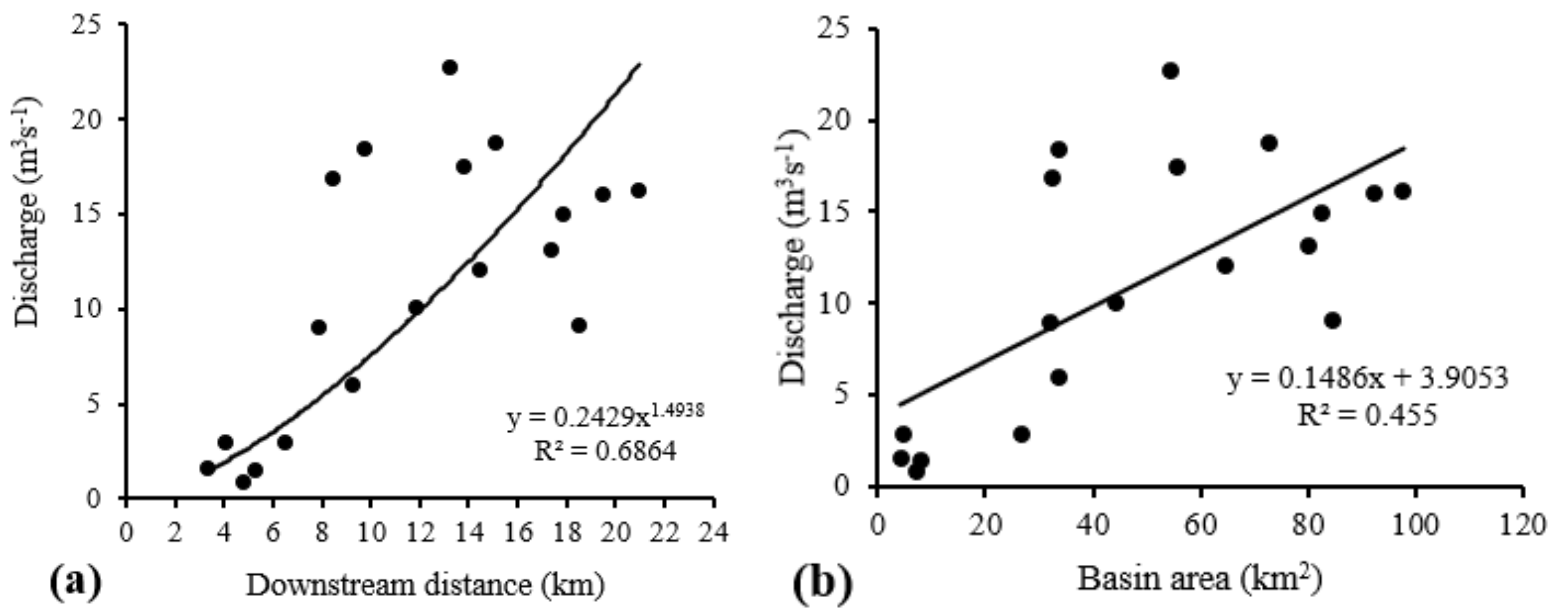

Figure 7: Graph showing (a) discharge and downstream distance relation, and (b) Hydraulic geometry relations of the Karra Khola 
Sediment Dynamics and Stability Status of The Karra Khola, Hetauda Dun Valley, Central Nepal Sub-Himalaya

\subsection{SEDIMENT TRANSPORT CAPACITY}

The maximum and minimum bed load transport (Table 3), are respectively, 1,063,206 $\mathrm{t} \mathrm{yr}^{-1}$ (at T13) and 3,515 $\mathrm{t} \mathrm{yr}^{-1}$ (at T4). The suspended sediment load varies from 2,095 $\mathrm{t} \mathrm{yr}^{-1}$ (at T3) to 109,550 $\mathrm{yr}^{-1}$ (at T9) (Table 3). Except for transects T2 to T5, where the suspended sediment load is less than 10,000 $\mathrm{t} \mathrm{yr}^{-1}$, and transect T9 where it is the highest, the suspended load tends to vary roughly between 10,000 $\mathrm{t} \mathrm{yr}^{-1}$ and 60,000 $\mathrm{t} \mathrm{yr}^{-1}$. The total sediment load fluctuates along the main stem course and varies from $8073 \mathrm{t} \mathrm{yr}^{-1}$ to $1077220 \mathrm{t} \mathrm{yr}^{-1}$. Transects 4 and 5 reveal lower total sediment load compared to the other transects.

Table 3: Bedloads, suspended loads, total load and total sediment yield of the Karra Khola and its tributaries

\begin{tabular}{|c|c|c|c|c|c|c|c|c|}
\hline $\begin{array}{c}\text { Transect } \\
\text { no. }\end{array}$ & $\begin{array}{c}\text { Watershed } \\
\text { Area }\left(\mathrm{km}^{2}\right)\end{array}$ & $\begin{array}{c}\text { Width } \\
(\mathrm{m})\end{array}$ & $\begin{array}{c}\mathrm{q}_{\mathrm{b}} \mathrm{X} \\
10^{-5} \\
\left(\mathrm{~m}^{2} \mathrm{~s}^{-1}\right)\end{array}$ & $\begin{array}{c}\mathrm{Q}_{\mathrm{b}} \\
\left(\mathrm{KNs}^{-1}\right)\end{array}$ & $\begin{array}{c}\mathrm{Q}_{\mathrm{b}}, \mathrm{bed} \text { load } \\
\left(\mathrm{t} \mathrm{yr}^{-1}\right)\end{array}$ & $\begin{array}{c}\text { Suspended } \\
\text { sediment } \\
\left(\mathrm{t} \mathrm{yr}^{-1}\right)\end{array}$ & $\begin{array}{c}\text { Total } \\
\text { Sediment } \\
\text { loads }\left(\mathrm{t} \mathrm{yr}^{-1}\right)\end{array}$ & $\begin{array}{c}\text { Total } \\
\text { Sediment } \\
\text { Yield }\left(\mathrm{TSY}^{-1}\right. \\
\left(\mathrm{t} \mathrm{km}^{-2} \mathrm{yr}^{-1}\right)\end{array}$ \\
\hline $\mathrm{T} 1$ & 4.23 & 3.5 & 206.39 & 0.19 & 615596 & 10509 & 626105 & 148015 \\
\hline T2 & 4.58 & 9.1 & 18.02 & 0.04 & 139719 & 5268 & 144987 & 31656 \\
\hline T3 & 7.36 & 5.3 & 5.56 & 0.007 & 25129 & 2095 & 27223 & 3698 \\
\hline T4 & 7.95 & 6.7 & 0.615 & 0.001 & 3514 & 4558 & 8073 & 1015 \\
\hline T5 & 26.62 & 11.0 & 0.899 & 0.002 & 8428 & 6516 & 14943 & 561 \\
\hline T6 & 32.14 & 18.0 & 61.04 & 0.30 & 936247 & 54271 & 990518 & 30819 \\
\hline T7 & 32.59 & 16.4 & 25.56 & 0.11 & 357195 & 63084 & 420280 & 12896 \\
\hline T8 & 33.83 & 13.8 & 2.39 & 0.008 & 28159 & 26877 & 55036 & 1627 \\
\hline T9 & 33.86 & 9.0 & 45.09 & 0.10 & 345803 & 109550 & 455354 & 13448 \\
\hline T10 & 44.41 & 15.8 & 30.07 & 0.12 & 404897 & 21847 & 426744 & 9609 \\
\hline T11 & 54.66 & 16.0 & 22.54 & 0.10 & 307364 & 31429 & 338793 & 6198 \\
\hline T12 & 55.66 & 12.7 & 83.32 & 0.28 & 901781 & 22012 & 923793 & 16597 \\
\hline T13 & 64.77 & 19.4 & 64.31 & 0.33 & 1063206 & 14014 & 1077220 & 16631 \\
\hline T14 & 72.67 & 13.6 & 83.33 & 0.30 & 965745 & 41870 & 1007616 & 13866 \\
\hline T15 & 80.34 & 28.0 & 10.82 & 0.08 & 258131 & 21912 & 280043 & 3486 \\
\hline T16 & 82.44 & 25.3 & 6.26 & 0.04 & 135050 & 30194 & 165244 & 2004 \\
\hline T17 & 84.73 & 17.5 & 7.40 & 0.03 & 110420 & 22286 & 132706 & 1566 \\
\hline T18 & 92.58 & 23.0 & 7.64 & 0.05 & 149893 & 31186 & 181079 & 1956 \\
\hline T19 & 97.80 & 27.6 & 12.50 & 0.10 & 294032 & 18879 & 312911 & 3199 \\
\hline
\end{tabular}

The sediment yield of the river ranges from 561 to $148,015 \mathrm{t} \mathrm{km}^{-2} \mathrm{yr}^{-1}$. The sediment yield from the outlet of the Karra Khola is $3199 \mathrm{t} \mathrm{km}^{-2} \mathrm{yr}^{-1}$. The sediment yield abruptly decreases from T1 towards downstream, showing that the sediment yield tends to be high at source region, where the gradient of the river is high, and it tends to diminish along the river course (Table 3 ). The rate of sediment yield is not uniform, and varies along the Karra Khola, showing that deposition of sediments has taken place intermittently along its course.

The stream power $(\Omega)$ is the rate of potential energy expenditure against beds and banks of channel per unit length. The quantity of sediment flowing together with the water is highly dependent on energy of flowing water that is a stream power or also known as transport capacity (Bagnold 1966). The total stream power in maximum is 22.17 $\mathrm{KNs}^{-1}$ at T9 and in minimum is $0.11 \mathrm{KNs}^{-1}$ at T3 (Table 4).

The graphical representation (Fig. 8a) of the Table 4 data helps to visualize the downstream variation of the stream power of the river. The trend of variation is quite fluctuating between 5 and $25 \mathrm{KNs}^{-1}$, and the few lowest stream power in the upstream segments. The midstream segments have fluctuating trends due to variation in discharge. The specific stream powers provides sense of risk of erosion (Bizzi and Lerner (2015), and thus can be used to interpret the potential of stream erosion. Highly fluctuating trends of specific stream power has been obtained (Fig. 8b). 
Table 4: Stream power of the Karra Khola at different transects

\begin{tabular}{|c|c|c|c|c|c|}
\hline Transect & $\begin{array}{c}\text { Downstream Distance } \\
(\mathrm{km})\end{array}$ & $\begin{array}{c}\mathrm{S} \\
\left(\mathrm{mm}^{-1}\right)\end{array}$ & $\begin{array}{c}\mathrm{Q}, \\
\left(\mathrm{m}^{3} \mathrm{~S}^{-1}\right)\end{array}$ & $\begin{array}{c}\Omega, \\
\left(\mathrm{KNs}^{-1}\right)\end{array}$ & $\begin{array}{c}\omega \\
\left(\mathrm{Wm}^{-2}\right)\end{array}$ \\
\hline T1 & 3.40 & 0.066 & 1.55 & 10.00 & 2866.34 \\
\hline T2 & 4.09 & 0.0086 & 2.88 & 2.00 & 248.29 \\
\hline T3 & 4.83 & 0.0014 & 0.81 & 0.11 & 20.98 \\
\hline T4 & 5.34 & 0.0013 & 1.46 & 0.18 & 27.78 \\
\hline T5 & 6.54 & 0.0052 & 2.91 & 1.48 & 134.90 \\
\hline T6 & 7.94 & 0.0076 & 9.01 & 6.71 & 373.07 \\
\hline T7 & 8.49 & 0.0084 & 16.81 & 13.84 & 844.35 \\
\hline T8 & 9.27 & 0.0071 & 5.96 & 4.14 & 300.71 \\
\hline T9 & 9.78 & 0.0123 & 18.38 & 22.17 & 2463.37 \\
\hline T10 & 11.88 & 0.007 & 10.04 & 6.89 & 436.21 \\
\hline T11 & 13.24 & 0.007 & 22.65 & 15.54 & 971.78 \\
\hline T12 & 13.85 & 0.0035 & 17.45 & 6.00 & 471.61 \\
\hline T13 & 14.45 & 0.0095 & 12.01 & 11.18 & 576.75 \\
\hline T14 & 15.11 & 0.0105 & 18.70 & 19.25 & 1415.84 \\
\hline T15 & 17.41 & 0.009 & 13.11 & 11.57 & 413.25 \\
\hline T16 & 17.93 & 0.007 & 14.96 & 10.27 & 405.91 \\
\hline T17 & 18.52 & 0.006 & 9.06 & 5.33 & 304.62 \\
\hline T18 & 19.53 & 0.0052 & 15.95 & 8.13 & 353.64 \\
\hline T19 & 20.99 & 0.0062 & 16.18 & 10.00 & 356.44 \\
\hline
\end{tabular}

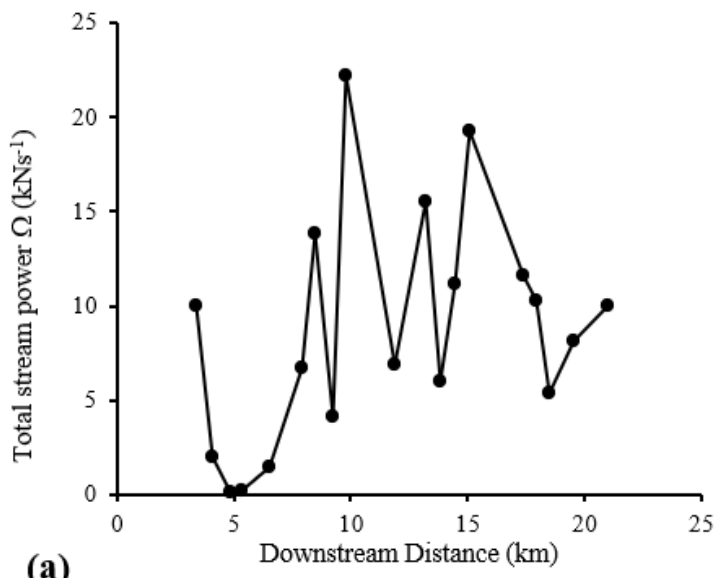

(a)

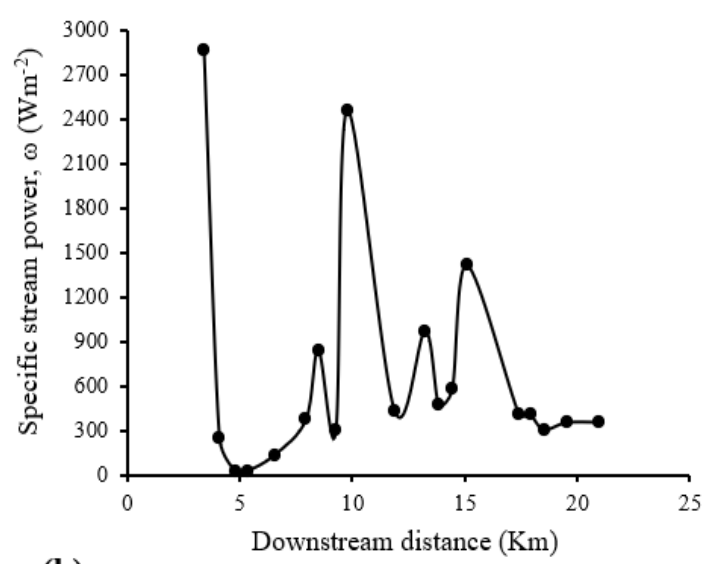

(b)

Figure 8: Graphical representation of (a) total stream power vs downstream distance, and (b) specific stream power vs. downstream distance

\subsection{COMPETENCE OF THE KARRA KHOLA}

Dimensionless boundary shear stress and dimensionless critical shear stress from different transects of the Karra Khola were calculated to analyse flow competence of the river. Both dimensionless shear stresses were compared to define flow competence. The Karra Khola is competent enough to transport the median sized sediments in most of the river transects, but it is still not competent enough to transport the median sized sediments at its lowermost sections T16, T17, T18, and T19 (Table 5). When competence of river was correlated with many variables, only the ratio of boundary shear stress to median grain size is found to give a good positive correlation. When this ratio, $\tau_{b} / d_{50}$ increases the competence of river tends to increase (Fig. 9). Therefore, at the river segments downstream from T16 transects (Table 5), most of median sized and coarser sediments are deposited on the river channels and bars due to great reduction in boundary shear stress and increased median grain size, and are supposed to be carried downstream only during flash floods. 
Sediment Dynamics and Stability Status of The Karra Khola, Hetauda Dun Valley, Central Nepal Sub-Himalaya

Table 5: Calculation of dimensionless Boundary shear stress and dimensionless critical shear stress using Shields (1936) relations

\begin{tabular}{|c|c|c|c|c|c|c|c|c|c|}
\hline Transect & $\begin{array}{c}\mathrm{R}_{\mathrm{h}} \\
(\mathrm{m}) \\
\end{array}$ & $\begin{array}{c}\mathrm{S} \\
\left(\mathrm{mm}^{-1}\right)\end{array}$ & $\begin{array}{l}\mathrm{d}_{50} \\
(\mathrm{~m})\end{array}$ & $\begin{array}{c}\tau_{\mathrm{b}} \\
\left(\mathrm{Nm}^{-2}\right)\end{array}$ & $\tau_{\mathrm{b}} / \mathrm{d}_{50}$ & $\tau_{\mathrm{b}}{ }^{*}$ & $\tau_{c} *$ & $\tau_{\mathrm{b}}{ }^{*} / \tau_{\mathrm{c}} *$ & Stability status \\
\hline T1 & 0.27 & 0.066 & 0.018 & 178.2 & 9900 & 0.58 & 0.053 & $10.94(\mathrm{C})$ & $\begin{array}{l}\text { Degradation with high } \\
\text { Transportation }\end{array}$ \\
\hline $\mathrm{T} 2$ & 0.39 & 0.008 & 0.011 & 31.2 & 2836 & 0.16 & 0.040 & $4.00(\mathrm{C})$ & Degradation \\
\hline T3 & 0.27 & 0.001 & 0.0002 & 2.7 & 13500 & 1.10 & 0.280 & $3.93(\mathrm{C})$ & Degradation \\
\hline $\mathrm{T} 4$ & 0.33 & 0.001 & 0.001 & 3.3 & 3300 & 0.25 & 0.061 & $4.10(C)$ & Degradation \\
\hline T5 & 0.42 & 0.005 & 0.025 & 21 & 840 & 0.05 & 0.047 & $1.06(\mathrm{C})$ & Degradation \\
\hline T6 & 0.55 & 0.008 & 0.021 & 44 & 2095 & 0.11 & 0.048 & $2.29(\mathrm{C})$ & $\begin{array}{c}\text { High Transportation and } \\
\text { lateral instability }\end{array}$ \\
\hline T7 & 0.68 & 0.008 & 0.042 & 54.4 & 1295 & 0.08 & 0.058 & $1.38(\mathrm{C})$ & $\begin{array}{c}\text { High Transportation and } \\
\text { lateral instability }\end{array}$ \\
\hline T8 & 0.47 & 0.007 & 0.027 & 32.9 & 1219 & 0.07 & 0.049 & $1.43(\mathrm{C})$ & Degradation \\
\hline T9 & 0.77 & 0.012 & 0.021 & 92.4 & 4400 & 0.26 & 0.052 & $5.00(\mathrm{C})$ & $\begin{array}{c}\text { High Transportation and } \\
\text { lateral instability }\end{array}$ \\
\hline $\mathrm{T} 10$ & 0.67 & 0.007 & 0.027 & 46.9 & 1737 & 0.10 & 0.050 & $2.00(\mathrm{C})$ & $\begin{array}{l}\text { High Transportation and } \\
\text { lateral instability }\end{array}$ \\
\hline T11 & 0.79 & 0.007 & 0.033 & 55.3 & 1676 & 0.1 & 0.054 & $1.85(\mathrm{C})$ & $\begin{array}{c}\text { High Transportation and } \\
\text { lateral instability }\end{array}$ \\
\hline T12 & 0.85 & 0.004 & 0.002 & 34 & 17000 & 0.87 & 0.032 & $27.19(\mathrm{C})$ & $\begin{array}{c}\text { High Transportation and } \\
\text { lateral instability }\end{array}$ \\
\hline T13 & 0.54 & 0.01 & 0.012 & 54 & 4500 & 0.25 & 0.044 & $5.68(\mathrm{C})$ & $\begin{array}{c}\text { High Transportation and } \\
\text { lateral instability }\end{array}$ \\
\hline T14 & 0.61 & 0.011 & 0.017 & 67.1 & 3947 & 0.22 & 0.048 & $4.58(\mathrm{C})$ & $\begin{array}{c}\text { High Transportation and } \\
\text { lateral instability }\end{array}$ \\
\hline T15 & 0.44 & 0.009 & 0.039 & 39.6 & 1015 & 0.06 & 0.054 & $1.11(\mathrm{C})$ & $\begin{array}{c}\text { High Transportation and } \\
\text { lateral instability }\end{array}$ \\
\hline T16 & 0.64 & 0.007 & 0.073 & 44.8 & 614 & 0.03 & 0.060 & $0.50(\mathrm{I})$ & Aggradation \\
\hline T17 & 0.56 & 0.006 & 0.048 & 33.6 & 700 & 0.04 & 0.056 & $0.71(\mathrm{I})$ & Aggradation \\
\hline $\mathrm{T} 18$ & 0.65 & 0.005 & 0.053 & 32.5 & 613 & 0.03 & 0.058 & $0.52(\mathrm{I})$ & Aggradation \\
\hline T19 & 0.62 & 0.006 & 0.055 & 37.2 & 676 & 0.04 & 0.059 & $0.68(\mathrm{I})$ & Aggradation \\
\hline
\end{tabular}

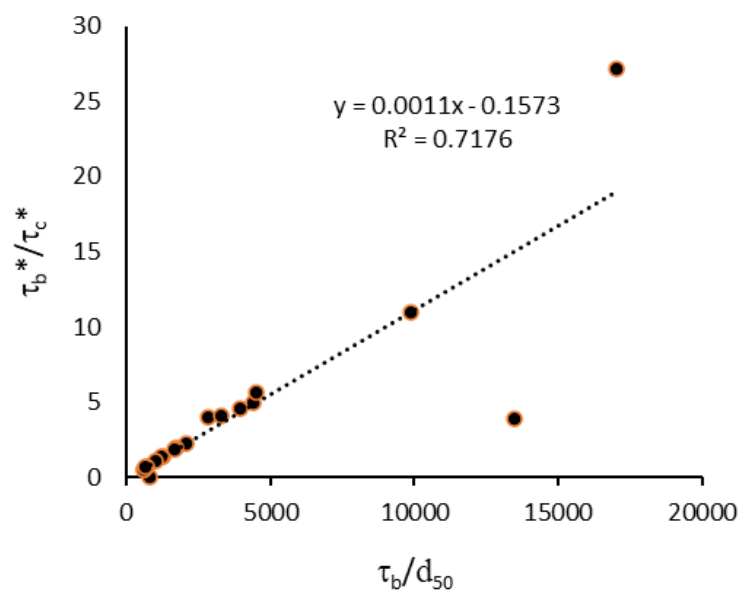

Figure 9: Relationship between flow competence and ratio of boundary shear stress to median grain size 
Naresh Kazi Tamrakar, and Suman Maharjan

\section{DISCUSSIONS}

The boulder-sized sediments which are resulted by mass wasting are found in the source region of the Karra Khola. From sampled sites towards downstream course of the river, grain size varies from clay to pebble, and there is a weak tendency of increase in median grain size with the distance downstream. Sediments are moderately well sorted to very poorly sorted, and often show textural inversion. The textural inversion is attributed to the mixing from the lateral tributaries of the Karra Khola. Slope and discharge of the river also play important roles for the transportation and deposition of sediments, as these parameters are among the governing factors in transport capacity and competence.

The discharge of the Karra Khola increases as the basin area increases, as in common hydraulic geometry of most of the rivers. (Singh 2003, Stewardson 2005, Navratil and Albert 2010). The number of contributing tributaries to the main stem increases as the basin area increases which is the main reason for increase in the discharge of the river downstream.

Sediment transport is critical to understand as it is influenced by many factors among which three fundamental factors are sediment supply, capacity, and competence. The capacity of rivers to transport sediments in suspension is proportional to their discharge and thus to rainfall and to the hydrologic properties of their drainage basin (Tucker and Slingerland 1997). The larger the river the higher the rate of sediment transportation. According to Mathur and Da Cunha (2001), the Hwang He River in China, which is also called Yellow River, carries 796 million tons per year and the Mississippi River of United States carries 406 million tons per year.

The sediment transport of the Karra Khola is dominated by bed load sediment, and the total sediment transport in the midstream is about a million tons per year, but it reduces at the extreme downstream transect and becomes three hundred thousand tons per year. Downstream reduction in slope and boundary shear stress and increase in $\mathrm{d}_{50}$ size are the main reasons for decreasing rate of bed load transport at the downstream stretch.

The sediment yield of the Kathmandu basin computed by Lama and Tamrakar (2016) for the Manahara River, Bagmati River and the Bishnumati River are respectively, 1,936,008 t km-2 $\mathrm{yr}^{-1}, 70,040 \mathrm{t} \mathrm{km}^{-2} \mathrm{yr}^{-1}$ and $44,530 \mathrm{t} \mathrm{km}^{-2} \mathrm{yr}^{-}$ 1. The sediment yield of the Karra Khola, which is 3,199 $\mathrm{t} \mathrm{km}^{-2} \mathrm{yr}^{-1}$, is very low compared to the sediment yields of the rivers of the Kathmandu basin. The sediment yields of the Karra Khola tend to diminish with downstream distance of the river.

Stream power is the function of slope and hydraulic radius. With fluctuation of hydraulic radius, stream power or transport capacity also fluctuates, therefore, transport capacity of the Karra Khola also varies with seasons. The maximum transport capacity calculated for the Karra Khola is $22.17 \mathrm{KNs}^{-1}$. The other major reason of fluctuations in the stream power is owing to the change in slopes along the river course. Bagnold (1966) found better correlation of stream power with sediment transport compared to that with shear stress.

The specific stream power of the Karra Khola ranges from $20.98 \mathrm{Wm}^{-2}$ to $2866.34 \mathrm{Wm}^{-2}$. There are various cases in which threshold specific stream powers vary in creating channel pattern changes and increasing in risk of erosion. Brookes et al. (1983) studied in Britain and found that small channels having specific stream powers $<35 \mathrm{Wm}^{-2} \mathrm{were}^{-}$ stable while channels with greater values were unstable. Miller (1990) studied stream power in regard to historic floods with extreme discharges in the central Appalachian Mountain and reported widespread erosion including scouring and channel widening had occurred at specific stream power between 200 and $500 \mathrm{Wm}^{-2}$, and sever erosion was recorded when the specific stream power was above $300 \mathrm{Wm}^{-2}$. Similarly, Magilliagan (1992) suggested that for the catastrophic modification of stream channel, the specific stream power must exceed $300 \mathrm{Wm}^{-2}$. Yochum et al. (2017) studied the rivers of Colorado Front Range after the flooding in 2013 and found for channel slopes less than $3 \%$, that there were substantial channel widening at SSP $>230 \mathrm{Wm}^{-2}$, and high potential for avulsion and pattern change at SSP $>480 \mathrm{Wm}^{-2}$, and also reported that there were possibility of infrequent to numerous eroded banks with SSP exceeding $700 \mathrm{Wm}^{-2}$. Considering, various researches the specific stream power of $300 \mathrm{Wm}^{-2}$, can be considered as the threshold for defining the boundary between low to high potential of river erosion and modification.

Stream power is capacity to transport sediments from the river channel, whereas dimensionless shear stress ratio is the measure of flow competence. The sediment starts to move only if the stress provided on the bed by the flow exceeds a critical shear stress value. That means when the dimensionless boundary shear stress exceeds the dimensionless critical shear stress of substrate sediment, the flow is competent enough to entrain and transport the 
river bed materials. As such situation applies to all the studied transects, except for the four downstream transects, the Karra Khola is found to be competent river up to the transect T15.

Costa and O'Conner (1995) showed that shear stress and stream power are indicators of the geomorphic work done by floods. In fact, the stability condition of the river is governed by a balance between river's transport capacity and competency. Three conditions arise after considering thresholds of specific stream power of $300 \mathrm{Wm}^{-2} \mathrm{and} \mathrm{of}$ flow competence of $\tau_{\mathrm{b}^{*}} / \tau_{\mathrm{c}^{*}}=1$ : (a) low capacity but with high competency, (b) high capacity with high competency, and (c) low capacity and low competency or high capacity but with low competency. In the first case, transport capacity is below the threshold in which severe erosion and channel modification is unlikely, but the river possesses high competency. In this situation, the river gets starved of sediments and may tend to erode its channel bed, thus undergoes degradation (e.g. T2 to T5, and T8). In the second case, where both transport capacity and flow competency are high, the sediments are transported without significant deposition because the river is competent enough to move the river bed materials. Such situation arises in T1, T6, T7, and T9 through T15. In the third case, whatever amount that the river transports, sediments tend to deposit due to incompetency of river to entrain and erode, therefore, allowing much of the sediments for deposition (e.g., T16, T17, T18 and T19).

\section{CONCLUSIONS}

The channel sediments of the Karra Khola are sandy gravel, gravelly to muddy sand, and gravelly to sand mud. The sediment distribution of the Karra Khola ranges from fine clay to boulder size, with median grain size ranging between 2 to $73 \mathrm{~mm}$, and are moderately well sorted to very poorly sorted. They are coarsely skewed in the upstream stretch and becomes nearly symmetrical to finely skewed in the mid to downstream stretches. Overall median grain size tends to diminish downstream, while other measures varies without a distinct trends. River discharge tends to increase with increase in downstream distance and with increase in basin area.

The total sediment load is 8073-1077220 $\mathrm{t} \mathrm{yr}^{-1}$, in which bed load dominates over suspended load except in few cases. The total sediment yield varies from 561 to $148015 \mathrm{t} \mathrm{km}^{-2} \mathrm{yr}^{-1}$, and that of the whole basin is only $3199 \mathrm{t} \mathrm{km}^{-}$ ${ }^{2} \mathrm{yr}^{-1}$, which is only around $2 \%$ of the maximum total sediment yield. The sediment yield does not follow its abundance with the increased basin area. The stream powers too vary along the distance downstream without a distinct trend of variation.

The Karra Khola possesses enough flow competence along its course except for the lower four transects located at the downstream segment. The nature of sediment transport capacity and flow competence of the Karra Khola is not uniform throughout its course, and it changes as the factors responsible for sediment transport changes. Both transport capacity and flow competency are taken to evaluate stability status of the Karra Khola. As a result, the upstream stretch of the river represents mainly degradation, the midstream stretch represents high rates of transport with lateral instability, and the downstream stretch represents aggradation. The midstream stretch of the river, which has high capacity, and competence of flow are laterally more erosive compared to the other stretches.

\section{SOURCES OF FUNDING}

This research received no specific grant from any funding agency in the public, commercial, or not-for-profit sectors.

\section{CONFLICT OF INTEREST}

The author have declared that no competing interests exist.

\section{ACKNOWLEDGMENT}

Authors are thankful to the Central Department of Geology for providing necessary facilities for this research. Authors also thank Miss Manju Subedi, Mr. Ananta Joshi and Mr. Rythum Rai for their assistance during field work. 
Naresh Kazi Tamrakar, and Suman Maharjan

\section{REFERENCES}

[1] Bagnold, R. A., 1960. Sediment discharge and stream power-A preliminary announcement: US Geological Survey, Circular 421, 23 p. Available online: https://pubs.usgs.gov/circ/1960/0421/report.pdf

[2] Bagnold, R.A., 1966. An approach to the sediment transport problem from general physics (Geological Survey professional paper 422-I). Washington. D.C., US Geological Survey, U. S. Government Printing Office, 1-37. Available online: https://pubs.usgs.gov/pp/0422i/report.pdf

[3] Bizzi, S. and Lerner, D.N., 2015. The Use of Stream Power as an Indicator of Channel Sensitivity to Erosion and Deposition Processes. River Research and Applications, 31 (1), 16-27. ISSN 1535-1459. Available online: https://doi.org/10.1002/rra.2717

[4] Brookes, A., Gregory, K. J., and Dawson, F.H., 1983. An assessment of river channelization in England and Wales. Science of The Total Environment, 27, Issues 2-3, 97-111, ISSN 0048-9697. Available online: https://doi.org/10.1016/0048-9697(83)90149-3

[5] Brookes A., 1987. The distribution and management of channelized streams in Denmark. Regulated Rivers: Research and Management, 1, 3-16. Available online: https://doi.org/10.1002/rrr.3450010103

[6] Cavazza, W., Zuffa, G.G., Camporesi, C., Ferretti, C., 1993. Sedimentary recycling in the temperate climate drainage basin (Senio River, north central Italy); Composition of source rock, soil profile, and fluvial deposits. In: M. J., Johnson, A., Basu, eds. Processes controlling the composition of clastic sediments. Colorado, U.S.A, Geological Society of America, Special Paper. 284, 247-260. Available online: file://C:/Users/Suman/Downloads/Cavazzaetal2000_p247-261\%20(1).pdf

[7] Chow, V.T., 1959. Open-channel hydraulics. New York, McGraw-Hill Book Co., 680 p. Available online: http://web.ipb.ac.id/ erizal/hidrolika/Chow\%20-\%200PEN\%20CHANNEL\%20HYDRAULICS.pdf

[8] Costa, J. E., and O'Conner J. E.., 1995. Geomorphically effective floods. In: J. E. Costa, A. J. Miller, K. W. Potter, and P. R. Wilcock, eds. Natural and anthropogenic influences in fluvial geomorphology, Geophysical Monograph series. Washington, D.C., USA, American Geophysical Union, 89, 45-56. Available online: https://agupubs.onlinelibrary.wiley.com/doi/pdf/10.1029/GM089

[9] Cowan, W. L., 1956, Estimating Hydraulic roughness coefficients. Agricultural Engineering, 37(7), 473-475.

[10] Cox, R. and Lowe, D.R., 1995. A conceptual review of regional-scale controls on the composition of clastic sediment and the co-evolution of continental blocks and their sedimentary cover. Journal of Sedimentary Research, A65(1), 1-12.

[11] Critelli, S., and Ingersoll, R. V., 1994. Sandstone petrology and provenance of the Siwalik Group (northwest Pakistan and western-southeastern Nepal). Journal of Sedimentary Research, A64, 815-823.

[12] DeCelles, P. G., Gehrels, G. E., Quade, J., Ojha, T. P., Kapp, P. A., and Upreti, B. N., 1998. Neogene foreland basin deposits, erosional unroofing, and the kinematic history of the Himalayan fold-thrust belt, Western Nepal. Geological Society of America Bulletin, 110, 2-21. Available online: https://doi.org/10.1130/00167606(1998)1102.3.CO;2

[13] Dickinson, W.R., Beard, L. S., Brakenridge, G.R., Erjavec, J.L., Ferguson, R.C., Inman, K.F., Knepp, R.A., Lindberg, F.A. and Ryberg, P.T., 1983. Provenance of North American Phanerozoic sandtones in relation to tectonic setting. Geological Society of America Bulletin, 94, 222-235.

[14] Dickinson, W.R., Lawton, T.F., and Inman, K.F., 1986. Sandstone detrital modes, central Utah Foreland region: Stratigraphic record of Cretaceous-Paleogene tectonic evolution. Journal of Sedimentary Petrology, 56 (2), 276-293.

[15] Du Boys, M. P., 1879. Le Rhone et less Rivieres a Lit affouillable. AAPG Memoir Documents, Annales Geophysicae, Pont et Chaussees, 5, 141-195.

[16] Einstein, H. A., 1950. The bedload function for sediment transportation in open channel flows. Technical Bulletin, 71, 1026国1037. Available online: https://naldc.nal.usda.gov/download/CAT86201017/PDF

[17] Ferguson R.I., 2005. Estimating critical stream power for bedload transport Calculations in gravel-bed rivers. Geomorphology, 70, 33-41. Available online: https://doi.org/10.1016/j.geomorph.2005.03.009

[18] Folk, R. L., and Ward, W. C., 1957. Brazos River bar: a study in the significance of grain size parameters. Journal of Sedimentary Petrology, 27, 3-26. Available online: https://doi.org/10.1306/74D70646-2B21-11D7$8648000102 \mathrm{C} 1865 \mathrm{D}$ 
Sediment Dynamics and Stability Status of The Karra Khola, Hetauda Dun Valley, Central Nepal Sub-Himalaya

[19] Galay, V., 1987. Erosion and sedimentation in the Nepal Himalaya, An assessment of river processes, Ministry of water resources HMG Nepal, Report no. 4/3/012587/1/1, 259p.

[20] Gautam, P., and Rösler, W., 1999. Depositional chronology and fabric of Siwalik group sediments in Central Nepal from magnetostratigraphy and magnetic anisotropy. Journal of Asian Earth Sciences, 17, 659-682. Available online: https://doi.org/10.1016/S1367-9120(99)00021-8

[21] Gilbert, G.K., 1914. The transportation of débris by running water, U.S. Geological Survey, Professional Paper, 86, 263. Available online: https://pubs.usgs.gov/pp/0086/report.pdf

[22] Grantham and Velbel, 1988. The influence of climate and topography on rock fragment abundance in modern fluvial sands of the Southern Blue Ridge Mountains. North Carolina, Journal of Sedimentary Petrology, 58, 219-227. Available online: https://pdfs.semanticscholar.org/687c/8850f366c45de0b57607edbf9696e7cd8399.pdf

[23] Hassanzadeh, Y., 2007. Evaluation of Sediments Load in a Natural River. Journal of Water International, 32, 145-154. Available online: https://doi.org/10.1080/02508060708691971

[24] Johnson, M.J., 1990. Tectonic versus chemical weathering controls on the composition of fluvial sands in tropical environments. Sedimentology, 37, 713-726. Available online: https://doi.org/10.1111/j.13653091.1990.tb00630.x

[25] Kimura, K., 1994. Formation and deformation of river terraces in the Hetauda Dun, Central Nepal. Institute of Geography, Faculty of Science, Tohoku University. 44(2), 151-181. Available online: https://core.ac.uk/download/pdf/235752734.pdf

[26] Kimura, K., 1995. Late Quaternary Morphotectonics of the Hetauda dun, Nepal sub- Himalaya. Journal of Nepal Geological Society, 11 (special issue), 225-235.

[27] Kizaki, K., 1994. An Outline of Himalayan Upheaval. Kathmandu, Jagadamba Prakashan, 127 p.

[28] Knighton, D. 1998. Fluvial Forms and Processes: A New Perspective. New York: Oxford University Press Inc. 383p. ISBN 0340663138.

[29] Lama, R., and Tamrakar, N. K., 2016. Dry season discharge and sediment yield of the northern tributaries of the Kathmandu Valley, Central Nepal. Bulletin of the Department of Geology, Tribhuvan University, Kathmandu, Nepal, 19, 29-44.

[30] Limerinos, J. T., 1970, Determination of the Manning coefficient from measured bed roughness in natural channels. U.S. Geological Survey, Water-Supply Paper, 1898-B, 47 p. Available online: https://pubs.usgs.gov/wsp/1898b/report.pdf

[31] Lorang, M.S. and Hauer, F.R., 2003. Flow competence and streambed stability: an evaluation of technique and application. Journal of North American Benthological Society, 22(4), 475-491. Available online: https://www.journals.uchicago.edu/doi/pdfplus/10.2307/1468347

[32] Magilligan, F. J., 1992. Thresholds and the spatial variability of flood power during extreme floods. Geomorphologv, 5, 373-390. Available online: https://doi.org/10.1016/0169-555X(92)90014-F

[33] Mao, L., Uyttendaele, G. P., Iroume, A., and Lenzi, M. A., 2008. Field based analysis of sediment entrainment in two high gradient streams located in Alpine and Andine environments. Geomorphology, 93, 368-383. Available online: https://doi.org/10.1016/j.geomorph.2007.03.008

[34] Mathur, A., and Da Cunha, D., 2001. Mississippi floods: Designing a shifting landscape. London: Yale University Press, $162 \mathrm{p}$.

[35] Meyer-Peter, E., and Muller, R., 1948. Formulas for Bedload Transport. In. 2nd meeting of the International Association for Hydraulic Structures Research. Stockholm, International Association for Hydraulic Structures Research, 39-64. Available online: https://repository.tudelft.nl/islandora/object/uuid\%3A4fda9b61-be284703-ab06-43cdc2a21bd7

[36] Miller, A. J., 1990. Flood hydrology and geomorphic effectiveness in the Central Appalachians. Earth Surface Processes Landforms, 15, 119-134. Available online: https://doi.org/10.1002/esp.3290150203

[37] Mua, K.E. and Shende, K.S., 2019. The Response of Stream Competence to Topographic and Seasonal Variations in the Bamenda-Menchum Drainage Basin, North West Region, Cameroon. Journal of Geography and Geology, 11(2), 21-34. Available online: https://doi.org/10.5539/jgg.v11n2p21

[38] Navratil, O. and Albert, M.B., 2010. Non-linearity of reach hydraulic geometry relations. Journal of Hydrology, 388, 280-290. Available online: https://doi.org/10.1016/j.jhydrol.2010.05.007

[39] Petit, F., Gob, F., Houbrechts, G., Assani, A.A., 2005. Critical specific stream power in gravel-bed rivers. Geomorphology, 69, 92-101. Available online: https://doi.org/10.1016/j.geomorph.2004.12.004 
Naresh Kazi Tamrakar, and Suman Maharjan

[40] Rathburn, S., 1993. Pleistocene cataclysmic flooding along the Big Lost River, east central Idaho. Geomorphology, 8, 305-319. Available online: https://doi.org/10.1016/0169-555X(93)90026-X

[41] Rosgen, D. L., 1996. Applied river morphoplogy. Wildland Hydrology Books. Colorado: Pagosa Springs, 378 p. Available online: https://www.leg.mn.gov/docs/2015/other/150681/PFEISref_2/Rosgen\%201996.pdf

[42] Rubey, W.W., 1933. Equilibrium conditions in debris-laden streams. Transaction of American Geophysical Union, 14, 497-505. Available online: https://doi.org/10.1029/TR014i001p00497

[43] Schelling, D., Cater, J., Seago, R., and Ojha, T.P., 1991. A balanced cross-section across the Central Nepal Siwalik Hills, Hetauda-Amlekhganj. Journal of Faculty of Science, Hokkaido University, Series IV, 23(1), Jul y., 1991, 19. Available online: http://hdl.handle.net/2115/36770

[44] Schoklitsch, A., 1934. Der Geschiebetrieb und die Geschiebefracht. Wasserkraft und Wasserwirtschaft, 29(4): 37-43.

[45] Shields A., 1936. Application of similarity principles, and turbulence research to bed load movement, Pasadena, CA: California Institute of Technology, Report 167. Available online: https://resolver.caltech.edu/CaltechKHR:HydroLabpub167

[46] Shrestha, M.B., Miyazaki, T., and Watanabe, K., 2005. Analysis of Siwalik and Mahabharat watersheds with geomorphometric parameters. In. International Symposium on Landslide Hazard in Orogenic from the Himalaya to Island Arc in Asia, Kathmandu, 321-333.

[47] Singh, V.P., 2003. On the theories of hydraulic geometry. International Journal of Sediment Research, 18(3), 196-218. Available online: http://geofaculty.uwyo.edu/neil/teaching/4880_files/HydraulicGeometry.pdf

[48] Soar, P.J., Wallerstein, N.P., and Thorne, C.R., 2017. Quantifying River Channel Stability at the Basin Scale. Water, 9, 1-3. Available online: https://doi.org/10.3390/w9020133 (accessed on 14th March 2019)

[49] Stewardson, M., 2005. Hydraulic geometry of stream reaches. Journal of Hydrology, 306, 97-111. Available online: https://doi.org/10.1016/j.jhydrol.2004.09.004

[50] Tamrakar, N. K., and Karki, B., 2019. Geomorphometric properties and variability of sediment deliery ratio and specific sediment yield ammong sub basins of the Karra River. Hetauda, Central Nepal Sub- Himalaya. Journal of Nepal Geological Society, 59, 19-37.

[51] Thompson, C. J. and Croke, J., 2013. Geomorphic effects, flood power, and channel competence of a catastrophic flood in confined and unconfined reaches of the upper Lockyer valley, southeast Queensland, Australia. Geomorphology, 197, 156-169. Available online: https://doi.org/10.1016/j.geomorph.2013.05.006

[52] Tokuoka. T., Takayasu, K., Yoshida, M., Hisatomi, K., 1986. The Churia (Siwalik) Group in the Western part of the Arung Khola area, West Central Nepal. Japan, Memoir of Faculty of Shimane University, 22, 1350210.

[53] Tucker, G. E., and Slingerland, R., 1997. Drainage basin responses to climate change. Water Resource Research, 33, 2031囵2047. Available online: https://doi.org/10.1029/2F97WR00409

[54] Van Rijn, L.C., 1984. Sediment Transport, Part I: Bed Load Transport. Journal of Hydraulic Engineering, American Society of Civil Engineers, 110(10), 1431-1456. Available online: https://doi.org/10.1061/(ASCE)0733-9429(1984)110:10(1431)

[55] Velikanov, M.A., 1955. Sediment and bed flow. eds. Dynamics of Alluvial Streams. Moscow, Russia: State Publishing House for Theoretical and Technical Literature, 2, 107-120.

[56] West, R. M., and Munthe, J., 1981. Neogene Vertebrate Paleontology and Stratigraphy of Nepal. Journal of Nepal Geological Society, 1, 1-14. Available online: https://ngs.org.np/neogene-vertebrate-paleontology-andstratigraphy-of-nepal/

[57] Whitaker, A.C. and Donald F. Potts, D.F., 2007. Analysis of flow competence in an alluvial gravel bed stream, Dupuyer Creek, Montana. Water Resources Research, 43, 1-16. Available online: https://doi.org/10.1029/2006WR005289

[58] Wilcock, D. N., 1971. Investigation into the Relations between Bedload Transport and Channel Shape. Geological Society of America Bulletin, 82 (8), 2159.

[59] Wolman, M. G., 1954. A method of sampling coarse river bed material. Transactions American Geophysics Union, 35, 951-956. Available online: http://dx.doi.org/10.1029/TR035i006p00951

[60] Yang, C. T., 1996. Sediment transport: theory and practice. New York: McGraw-Hill, 396p. Available online: http://infinity.wecabrio.com/read/70723095-sediment-transport-mcgraw-hill-series-in-water-reso.pdf 
Sediment Dynamics and Stability Status of The Karra Khola, Hetauda Dun Valley, Central Nepal Sub-Himalaya

[61] Yochum, S.E., Sholtes, J.S., Scott, J.A., Bledsoe, B.P., 2017. Stream power framework for predicting geomorphic change: The 2013 Colorado Front Range flood. Geomorphology, 292, 178-192. Available online: https://doi.org/10.1016/j.geomorph.2017.03.004 